\title{
Human Resource Development in Indian Railways - An Overview
}

\author{
V. Rajeswari ${ }^{1}$, K. Santa kumari ${ }^{2}$ \\ ${ }^{1}$ Research Scholar, Dept. of Economics, Sri Venkateswara University, Tirupati-517502 \\ ${ }^{2}$ Professor, Dept of Economics, Sri Venkateswara University, Tirupati -517502
}

\begin{abstract}
Service sector in India consists of a wide variety of services such as electricity, water supply, road, rail and air transport etc which provides a vast opportunities for HRD. Indian Railways is the backbone of service sector and one of the biggest employers in India. Indian Railways is one of the gigantic public undertakings enriched with fixed assets. viz: 64015 Route Kilometers, 7030 Railway Stations while the Railway Bridges are 1,30,776 in number. About 29 percent of total route kilometers has electrification network in Indian Railways. The Indian Railways Fleet is substantial with 4963 Diesel Traction, and 3586 Electrical Traction, while 2, 11,763 Wagons, and 49110 Passenger service Vehicles.

The total strength of Human Resource in Indian Railways is at 13.28 Lakhs during the year 2010-11. The Medical and Health services of employees are taken care with the help of 121 Hospitals and 586 Health units. Apart from that the 133 private hospitals recognized for medical treatment also do render the yeomen services. About 46 percent of the employees are provided with Railway Accommodation facilities. The total area of 4.31 lakhs in hectares of Land is the hallmark of Indian Railways. Indian Railways carried 19 million passengers and 2.29 million tons of freight each day during the year 2008-09.

The Railway Board synchronizes of scare resources with the help of Human Resource in Indian Railways. Human resource helps not only in tapping the fixed and scare resources of organization in an effective and efficient way but also in attaining the goals of organization in a rapid manner. In fact, they are the real assets of Indian Railways. Hence, the present paper proposes to examine on Human Resource Management--A study of Indian Railways since 1950-51 to 2010-11. It concluded that the total costs of Human Resource reduce is substantial at Rs.3,273.46 crore during the above study period. In forthcoming 5 years the Human Resource strength may further decline in Indian Railways and in turn the Human Resource strength might be as low as 12 Lakhs by 2014-15.
\end{abstract}

Keywords: Service Sector, Indian Railways, Human Resource Development.

\section{Introduction}

The core aim of Human Resource Management is to attain the organization effectiveness. Human Resource Management includes the following key aspects viz:

1. Human Resource Planning

2. Recruitment and Selection

3. Training and Development

4. Reward Management and

5. Human Relations.

Human Resource Planning aims at anticipating the movement of Human Resource in the organization on account of Turnovers, Transfers, Retirement and Promotions. Recruitment and Selection aims at to select the right person at the right place. Training helps in upgrading the skills, knowledge and attitudes while Development is to enhance the skills, knowledge, and Personality Development. Training and Development helps in synchronization of Human Resource in an effective manner for achieving the goals of the organization. Reward Management is one of the tools for encouraging the desired employee behaviors while the Human Relations will help in boosting the morale of the employees.

Of all the resources, the Human Resource is vital for utilization of scarce resources in an effective and efficient manner. The author of Personnel Management C B. Mamoria states that the organizations performance and resulting productivity are directly proportional to the quality and quantity of human resources, hence, the significance of the Human Resource.

Service sector is the life line of the economic growth of the country. Transport is one of the service sectors in India. Indian Railways caters to the needs of the commuters and movement of bulky goods for longer distances in India. Indian Railways are the life line of India. Indian Railways are the cheapest, fastest and safest means of transport in India in comparison to Roadways.

Indian Railways is one of the gigantic public undertakings enriched with fixed assets. viz: 64015 Route Kilometers, 7030 Railway Stations while the Railway Bridges are 1, 30,776 in number. About 29 percent of Total Route kilometers has Electrification network in Indian Railways. The Indian Railways Fleet is substantial 
with 4963 Diesel Traction, and 3586 Electrical Traction, while 2, 11,763 Wagons, and 49110 Passenger service Vehicles.

The total strength of Human Resource in Indian Railways is at 13.28 Lakhs during the year 2010-11. The Medical and Health services of employees are taken care with the help of 121 Hospitals and 586 Health units. Apart from that the 133 private hospitals recognized for medical treatment also do render the yeomen services. About 46 percent of the employees are provided with Railway Accommodation facilities. The total area of 4.31 Lakhs in hectares of Land is the hallmark of Indian Railways. Indian Railways carried 19 million passengers and 2.29 millions tones of freight each day during the year 2008-09.

The Railway Board synchronizes of scare resources with the help of Human Resource in Indian Railways. Human resource helps not only in tapping the fixed and scare resources of organization in an effective and efficient way but also in attaining the goals of organization in a rapid manner. In fact, they are the real assets of Indian Railways. Hence, the present paper proposes to examine on Human Resource Management--A study of Indian Railways since 1950-51 to 2010-11 with the help of the following core objectives:

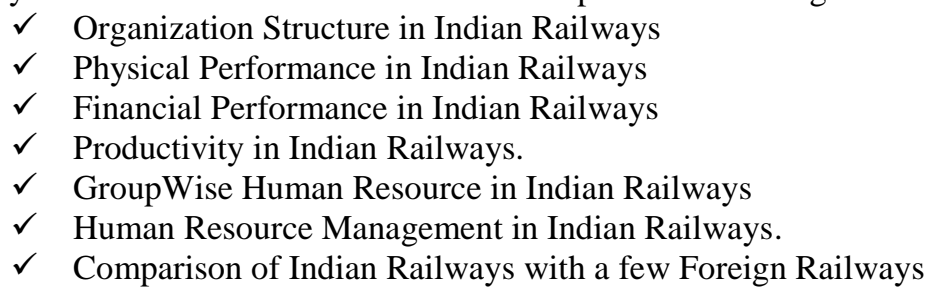

Fig : 1 Organisational Structure Of The Indian Railways

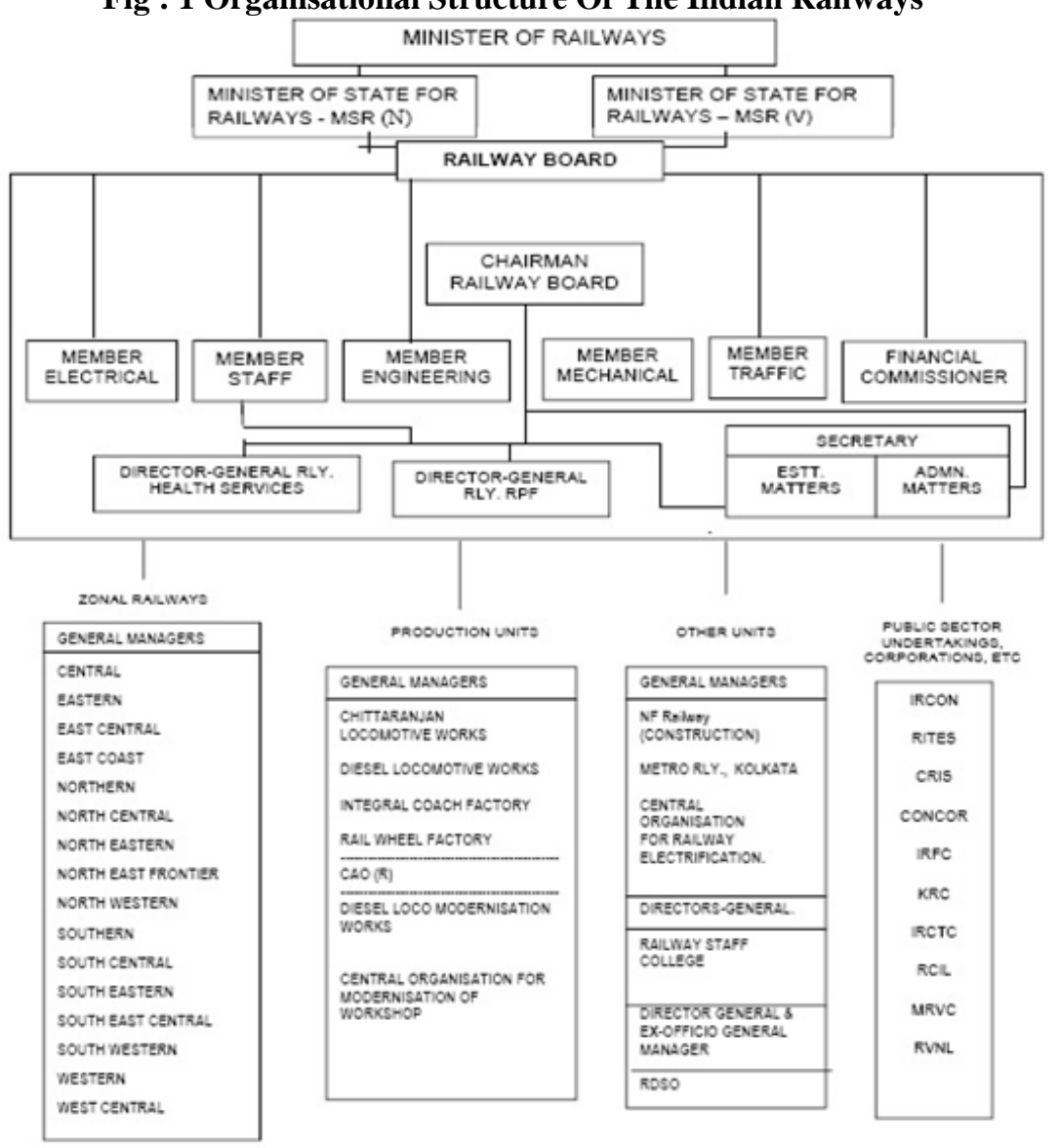

\section{Research Methodology}

The Research Methodology of the study includes the above core objectives. The data is collected from the secondary source. The period of study is from 1950-51 to 2010-11. The statistical tools are applied in accordance to the requirements of the study purpose.

Indian Railways is governed by three tier vertical organization structure. It reveals the flow of authority from top to bottom of the organization in a vivid manner. Indian Railways is Headed and Governed by Union Minister of Railways, two Ministers of State for Railways, Chairman Railway Board, Financial Commissioner, 
Member Staff, Member Electrical, Member Mechanical, Member Engineering and Member Traffic at the apex level,. The Railway Board takes the right decisions at the right time and right place. It is the supreme decision making body in Indian Railways.

General Managers of 16 Zonal Railways at the zonal level and the lowest level of 68 Divisions headed by Divisional Railway Managers for effective and efficient management of scare resources in order to attain the goals of the organization in a rapid manner.

Table-1 : Physical Performance Of Indian Railways

\begin{tabular}{|l|l|l|l|}
\hline Year & Route Kms & $\begin{array}{l}\text { Number of Railway } \\
\text { Stations }\end{array}$ & Electrifications in KMS \\
\hline $1950-51$ & 53596 & 5976 & 388 \\
\hline $1960-61$ & 56247 & 6523 & 748 \\
\hline $1970-71$ & 59790 & 7066 & 3706 \\
\hline $1980-81$ & 61240 & 7035 & 5345 \\
\hline $1990-91$ & 62367 & 7100 & 9968 \\
\hline $2000-01$ & 63028 & 6843 & 14856 \\
\hline $2008-09$ & 64015 & 7030 & 18559 \\
\hline $2009-10$ & 63974 & 7083 & 18927 \\
\hline $2010-11$ & 64460 & 7133 & 10233 \\
\hline Mean & 60968.56 & 6865.44 & 77.84 \\
\hline$C V$ & 6.21 & 5.59 & 27.79 \\
\hline LGR & 2.10 & 1.47 & $12.794 * *$ \\
\hline$t$-value & $9.887 * *$ & $3.087^{*}$ & \\
\hline
\end{tabular}

Source: Indian Railway Statistical Summary 2011

Table 1 indicates that the socio-economic development in India is through the development of the railway stations. The number of railway stations in Indian Railways is at 7133 during the year 2010-11 in contrast to 5976 railway stations during the year 1950-51.

The network of Indian Railways is through route kilometers. The route kilometers in Indian Railways are 64460 during the year 2010-11 in contrast to 53596 route kilometers during the year 1950-51. The route kilometers have increased by 19 percent during the above study period. The density of human resource per kilometer in Indian railways is at 26 per kilometer during the year 2010-11.

Table 2 : Networks of Indian Railways

\begin{tabular}{|l|l|l|l|l|}
\hline Year & Number of DSL Engines & $\begin{array}{l}\text { Number of Electric } \\
\text { Engines }\end{array}$ & Number of Wagons & $\begin{array}{l}\text { Number } \\
\text { Passenger Vehicles }\end{array}$ \\
\hline $1950-51$ & 17 & 72 & 205596 & 13022 \\
\hline $1960-61$ & 181 & 131 & 307907 & 20062 \\
\hline $1970-71$ & 1169 & 602 & 383990 & 24591 \\
\hline $1980-81$ & 2403 & 1032 & 400946 & 27410 \\
\hline $1990-91$ & 3759 & 1743 & 346102 & 28677 \\
\hline $2000-01$ & 4702 & 2810 & 222193 & 33236 \\
\hline $2008-09$ & 4963 & 3586 & 211763 & 49110 \\
\hline $2009-10$ & 5346 & 4287 & 220549 & 51050 \\
\hline $2010-11$ & 6132 & 5224 & 229381 & 53220 \\
\hline Mean & 3185.78 & 2165.22 & 280936.33 & 33375.33 \\
\hline$C V$ & 72.67 & 87.50 & 28.20 & 43.42 \\
\hline LGR & 26.08 & 31.42 & -4.09 & 15.41 \\
\hline$t$-value & $16.20^{* *}$ & $7.316^{* *}$ & $-0.994^{@}$ & $7.711^{* *}$ \\
\hline
\end{tabular}

Note : **significant at 1 per cent level; @ - Not significant

Source: Indian Railway Year books- 1950-51 to 2010-2011

Table:2 shows the fleet in the Indian Railways is the Diesel Engines, Electrical Engines, Wagons and Passenger Vehicles. The number of Diesel Engines in Indian Railways is 5137 during the year 2010-11 in contrast to 17 Diesel Engines during the year 1950-51

The Electrification network in Indian Railways is at 19607 kilometers during the year 2010-11 in contrast to 388 route kilometers during the year 1950-51. The Electrification network to the total route kilometers in Indian Railways t-test has been used, shows significance in all aspects like route kilometers, number of Railway stations and Railway Electrification in kilometers. There is significant growth has been achieved by the Indian Railways in last seven decades. LRG and CGR shows positive magnitude in Indian Railway networks.

The number of Electrical Engines in Indian Railways is at 5224 during the year 2010-11 in contrast to 72 during the year 1950-51.. The Electrical Engines should increase further in order to render the best services 
to the movement of Goods and commuters. The Electrical Engines are eco-friendly, faster and the cheapest in comparison to the Diesel Engines.

The Wagons turn the wheel of the profits. The number of Wagons in Indian Railways is 229381 during the year 2010-11 in contrast to 205596 wagons during the year 1950-51..

The number of Passenger Vehicles in Indian Railways is 53220 during the year 2010-11 in contrast to 13022 during the year 1950-51. T-test has been used, shows significance in diesel engines, electric engines and passenger vehicles but shows Not Significant in case of number of wagons during the above study period. Thus significant progress has been achieved by railways in diesel engines, electrical engines and passenger vehicles. The linear Growth shows negative growth in case of number of wagons. The passenger vehicles have increased in accordance to the commuters demand.

Table:3 indicates the Financial performance is viewed through Gross Revenue and Net Revenue in Indian Railways. The Gross Revenue in Indian Railways is 94535.63crore during the year 2010-11 in contrast to 263.30 crore during the year 1950-51. The Gross Revenue has increased substantially by 310 fold during the above study period.

The Net revenue reflects the contribution of the Indian Railways to the Indian exchequer The Net Revenue in Indian Railways is Rs 6346.14 crore in 2010-11 in contrast to Rs 47.56 crore during the year 195051. The Net revenue has increased significantly by about 192.9 Fold during the above period. The higher the net revenue depicts the greater the financial soundness.

The Total cost in Indian Railways is Rs 88189.49 crore in $2010-11$ in contrast to 215.74 crore during the year 1950-51. The total cost has increased substantially by 337.66 fold during the above study period. The operating ratio is at 95percent during the year 2010-11 in contrast to 81 percent during the year 1950-51. The operating ratio depicts the efficiency of management.

The Human Resource cost in Indian Railways is at Rs 39940 crore during the year 2008-09 in contrast to Rs 113.80 crore during the year 1950-51. The cost of Human resource has increased significantly by 351 fold during the above period. The Human Resource cost to the total cost in Indian Railways is at 55 percent depicting a lion's share to the total cost in Indian Railways.

Table-3 : Financial Performance In Indian Railways

\begin{tabular}{|l|l|l|l|l|}
\hline YEAR & $\begin{array}{l}\text { Gross Revenue Rs. in } \\
\text { Crore }\end{array}$ & $\begin{array}{l}\text { Net Revenue Rs. In } \\
\text { crore }\end{array}$ & $\begin{array}{l}\text { Total Cost Rs. in } \\
\text { Crore }\end{array}$ & $\begin{array}{l}\text { Human Resource } \\
\text { Cost Rs. in Crore }\end{array}$ \\
\hline $1950-51$ & 263.30 & 47.56 & 215.74 & 113.8 \\
\hline $1960-61$ & 460.42 & 87.87 & 372.55 & 205.2 \\
\hline $1970-71$ & 1006.95 & 144.73 & 862.22 & 459.9 \\
\hline $1980-81$ & 2703.48 & 127.49 & 2575.99 & 1316.7 \\
\hline $1990-91$ & 12451.55 & 1113.78 & 11337.77 & 5166.3 \\
\hline $2000-01$ & 36010.95 & 1071.23 & 34939.72 & 18841.0 \\
\hline $2008-09$ & 81658.98 & 9174.45 & 72848.53 & 39940.0 \\
\hline $2009-10$ & 86963.97 & 5544.00 & 81419.97 & 51719.4 \\
\hline $2010-11$ & 94535.63 & 6346.14 & 88189.49 & 53706.9 \\
\hline Mean & 35117.25 & 2628.58 & 32529.11 & 19052.13 \\
\hline$C V$ & 117.10 & 131.39 & 116.79 & 121.28 \\
\hline LGR & 39.45 & 38.40 & 39.52 & 40.71 \\
\hline$t$-value & $4.758^{* *}$ & $3.360^{*}$ & $4.800^{* *}$ & $4.405 * *$ \\
\hline
\end{tabular}

Note: **significant at 1 per cent level; *significant at 5 per cent level.

Source: Indian Railways Statistical Summary-2011

Table:4 shows the operating ratio in Indian Railways 81percent in1950-51,the same has increased to 95percent by 2010-11. The Gross Revenue per employee is increasing greater than the Human Resource cost per employee during the study period the value added depicts the contribution of the Human Resource. The value added is arrived by gross revenue per employee reduced by the human resource cost per employee. The Value Added by the Human Resource in Indian Railways is at Rs 3073.99 during the year 2010-11 in contrast to Rs 1636 during the year 1950-51. The value added by the human resource has increased substantially during the above study period. 
Table : 4 Operating Ratio, Human Resource Cost in Indian Railways

\begin{tabular}{|l|l|l|l|l|}
\hline YEAR & $\begin{array}{l}\text { Operating } \\
\text { Ratio in } \\
\text { percentage }\end{array}$ & $\begin{array}{l}\text { Gross Revenue Per } \\
\text { Employee in Rs. }\end{array}$ & $\begin{array}{l}\text { Human Resource } \\
\text { Cost per Employee } \\
\text { in Rs. }\end{array}$ & $\begin{array}{l}\text { Value Added } \\
\text { in Rs. }\end{array}$ \\
\hline $1950-51$ & 81 & 2882 & 1246 & 1636 \\
\hline $1960-61$ & 79 & 3979 & 1774 & 2205 \\
\hline $1970-71$ & 84 & 7327 & 3347 & 3980 \\
\hline $1980-81$ & 96 & 17195 & 8375 & 8820 \\
\hline $1990-91$ & 92 & 75381 & 31276 & 44105 \\
\hline $2000-01$ & 98 & 233035 & 121924 & 11111 \\
\hline $2008-09$ & 90 & 589170 & 288167 & 301003 \\
\hline $2009-10$ & 95 & 6384.55 & 3797.03 & 2587.52 \\
\hline $2010-11$ & 95 & 7117.57 & 4043.59 & 3073.99 \\
\hline
\end{tabular}

Source: Indian Railways year books from1950-51 to 2010-2011

It shows the increasing trend in all the parameters taken that is operating ratio, Gross revenue, Human resource cost and Value added in rupees.

Table:5 shows in Indian Railways the Human Resource are classified into four groups viz: group $\mathrm{A} \& \mathrm{~B}$, consisting of Officers Cadre, while group $\mathrm{C}$ and group of D as non Gazetted cadre. the Human resource strength of group A and B officers in Indian Railways were 16.8 thousands during the year 2010-11 in contrast to 2.3 thousands during the year 1950-51The Human Resource strength of group C staff in Indian Railways is 1076.9 Lakhs during the year 2010-11 in correspondence to 2.23 Lakhs human resource during the year 195051. The Human Resource strength of group D staff in Indian Railways is 234.5 Lakhs during the year 2010-11 in contrast to 6.87 Lakhs during the year 1950-51.

Table-5 : Group Wise Human Resource And Productivity In Indian Railways

\begin{tabular}{|c|c|c|c|c|}
\hline YEAR & $\begin{array}{ll}\text { GROUP } & \text { A\&B } \\
\text { officers }\end{array}$ & $\begin{array}{ll}\text { GROUP } & \mathrm{C} \\
\text { Employees } & \end{array}$ & $\begin{array}{ll}\text { GROUP } & \text { D } \\
\text { Employees } & \\
\end{array}$ & $\begin{array}{l}\text { Total Human Resource in } \\
\text { Indian Railways }\end{array}$ \\
\hline $1950-51$ & 2.3 & 223.5 & 687.8 & 913.6 \\
\hline $1960-61$ & 4.4 & 463.1 & 689.5 & 1157.0 \\
\hline $1970-71$ & 8.1 & 583.2 & 782.9 & 1374.2 \\
\hline $1980-81$ & 11.2 & 721.1 & 839.9 & 1572.2 \\
\hline $1990-91$ & 14.3 & 891.4 & 746.1 & 1651.8 \\
\hline $2000-01$ & 14.8 & 900.3 & 630.2 & 1545.8 \\
\hline $2008-09$ & 16.4 & 913.3 & 456.3 & 1386.0 \\
\hline $2009-10$ & 16.7 & 926.5 & 418.9 & 1362.1 \\
\hline $2010-11$ & 16.8 & 1076.9 & 234.5 & 1328.2 \\
\hline Mean & 11.67 & 744.37 & 609.57 & 1365.66 \\
\hline$C V$ & 47.37 & 36.64 & 32.56 & 16.51 \\
\hline$L G R$ & 16.44 & 12.64 & -9.54 & 2.77 \\
\hline$t$-value & $16.295 * *$ & $9.676 * *$ & $-2.598^{@}$ & $1.856^{@}$ \\
\hline
\end{tabular}

Note : **significant at 1 per cent level; @ - Not significant

Source: Indian Railway Year Books from 1950-51 to 2010-2011

The Total strength of Human Resource in Indian Railways is at 13.28 Lakhs in 2010-11 contrast to 9.14 Lakhs human resource strength during the year 1950-1951. T-test has been used, shows significance in at 1percent in group A, B, C employees but shows not significant in case of group D employees. The Total Human Resource strength is showing not significant in Indian Railways. The Linear growth rates and Compound Growth rates in case of Group A, B, C and Total employees but shows negative Growth in case of Group D employees.

The one of the core aspects of Human Resource Management is Human Resource Planning. The Human Resource Planning is a global phenomenon. Human Resource Planning in Indian Railways aims at twin objectives like: right sizing of the human resource strength on one hand and reducing the human resource cost on the other.

The Human Resource Planning in Indian Railways is reflected through the strategy of trimming the Human Resource strength since 1990-91 to 2010-11. The Human Resource strength was 16.51 Lakhs during the year 1990-91 in contrast to 13.28 Lakhs during the year 2010-11.

Suddhendu Biswas, author of Statistical Techniques of Human Resource Planning and Forecasting was of the view that the basic idea in human Resource planning is to match the supply of human resources with that of the demand. Once the work load versus employment relationship is known one can use the relation for projection of future human resource. 
Raymond A. Noe and Patrick. M Wright. Authors of Human Resource Management have aptly stated that the downsizing aims at the planned elimination of large numbers of personnel to enhance organizational competitiveness. The rightsizing the Human Resource is the order of the day in the entire globe.

The Human Resource strength in Indian Railways has decline by 2.66 Lakhs during the above study period. From the percentage point of view it is 19 percent of Human resource is reduced during the above study period. In forthcoming 5 years the Human Resource strength may further decline in Indian Railways and in turn the Human Resource strength might be as low as 12.5 Lakhs by 2012-13.

The total Human Resource right sized is 2.66 Lakhs during the year 1990-91 to 2010-11. The Total average cost of Human Resource reduced in Indian Railways is at Rs 3,273.46 crore (2, 66, 000 X Average Human Resource Cost) during the above study period. The reduction of Human resource cost is quite substantial in nature and in turn is reflected in the net revenue generation. The Human Resource reduction cost is one of the avenues to generate more Net Revenue in Indian Railways.

Recruitment and Selection is one of the important aspects in the Human Resource Management. The group A and B officers are recruited by the UPSC while the group C and D staff is recruited by the 20 Railway Recruitment Boards in Indian Railways. However, the number of Railway Recruitment Boards should be reduced drastically to five in number. The RRBs should follow the recruitment and selection pattern on par with the UPSC

The Training and Development in Indian Railways is one of the important aspects of Human Resource Management. Railway Staff College and the six Centralized Training Institutes in Indian Railways impart Training and Development to officers to develop into World Class Executives. About 5171Gazetted officers are trained and developed every year. They render yeomen's service in Indian Railways.

The Zonal Railway Institutes impart training to the group C and D staff in Indian Railways. The number of staff trained are 3,19 910 during the year 2008-09 in contrast to 121181 staff trained during the year 1950-51. The number of staff trained has increased substantially by 164 percent during the above study period.

The pay is the basic input for motivating the employees. Reward management aims at to retain, and sustain the employees. Hence, once in a decade pay commission are set up in order to restructure the pay scales in Indian Railways. The 4th 5th and 6th pay commission recommended the revised pay scales w.e.f 1.1.1986., 1.1.1996, and 1.1.2006 respectively. The implementation of the 6th pay commission resulted in decline of the net revenue during the year 2008-09.

Table: 6 Productivity of NTKMS

\begin{tabular}{|c|c|c|}
\hline YEAR & $\begin{array}{l}\text { Productivity } \\
\text { PKMS in Billions }\end{array}$ & $\begin{array}{l}\text { Productivity } \\
\text { NTKMS in Billions }\end{array}$ \\
\hline $1950-51$ & 66.51 & 37.56 \\
\hline 1960-61 & 77.66 & 72.33 \\
\hline $1970-71$ & 118.12 & 110.69 \\
\hline $1980-81$ & 208.64 & 147.65 \\
\hline $1990-91$ & 295.64 & 235.78 \\
\hline $2000-01$ & 457.02 & 312.37 \\
\hline $2008-09$ & 838.03 & 551.44 \\
\hline $2009-10$ & 897.31 & 664.61 \\
\hline $2010-11$ & 922.43 & 732.81 \\
\hline Mean & 431.26 & 318.36 \\
\hline$C V$ & 83.95 & 83.44 \\
\hline$L G R$ & 29.26 & 29.34 \\
\hline$t$-value & $6.135 * *$ & $5.724 * *$ \\
\hline
\end{tabular}

Note : **significant at 1 per cent level

Source : Indian Railway Year Books1950-51 to 2010-2011

The Productivity in Indian Railways is reflected through traffic output i.e. Passenger Kilometers (PKMS) and Net Tone Kilometers (NTKMS). PKMS are 922.43 Billions in 2010-11 in contrast to 66.51 Billion PKMS during the year 1950-51. PKMS has increased tremendously during the above period.

NTKMS are 732.81 billions in Indian Railways during the year 2010-11 in contrast to 37.56 NTKMS in billions during the year 1950-51. NTKMS has increased substantially in Indian Railways above period. T-test has been used, shows significance in passenger kilometers and net tone kilometers. Thus significant progress has been achieved by railways in last seven decades. The linear growth rates and compounding growth rates are in increasing trend. The higher the productivity reveals the higher the output. The Productivity is highly significant. The substantial Net revenue is primarily on account of efficiency in management of Human Resources and contributed to Indian exchequer by Indian Railways. The Railway Board deserves high degree of credit for the spectacular achievement

Apart from that the Productivity Linked Bonus (PLB) is an incentive given to the group C and D staff in Indian Railways. The PLB is at 75 days wage pay during the year 2008-09 in contrast to 46 days wage pay 
during the year 1950-51. The increase in PLB is by 63 percent during the above study period. However the productivity linked bonus benefit should be extended to the group A and B officers in Indian Railways.

The Human Relations mean the relations between the employer and employees and employees and employees in the organization. Human Relations are paramount for the enhance in the productivity. The cordial relations are linked with the productivity. Better the human relations the higher the productivity and vice-versa. The AIRF and NFIR the recognized unions are playing a pivotal role in maintaining the cordial relations in Indian Railways by redressing the grievances of the employees in an amicable manner.

Table- 7 : Human Resource Management In Indian Railways

\begin{tabular}{|c|c|c|c|c|}
\hline Year & $\begin{array}{l}\text { Human Resource } \\
\text { Planning in Lakhs }\end{array}$ & $\begin{array}{l}\text { Training and Development of } \\
\text { officers in Numbers }\end{array}$ & $\begin{array}{l}\text { Training of Non-Gazetted } \\
\text { Staff in Numbers }\end{array}$ & $\begin{array}{l}\text { Productivity } \\
\text { Linked Bonus in } \\
\text { Days }\end{array}$ \\
\hline $1990-91$ & 16.52 & 5570 & 121181 & 46 \\
\hline $2000-01$ & 15.45 & 6074 & 219208 & 57 \\
\hline $2002-03$ & 15.11 & 5130 & 216518 & 59 \\
\hline 2003-04 & 14.72 & 4967 & 230782 & 59 \\
\hline 2004-05 & 14.42 & 4617 & 227852 & 59 \\
\hline $2005-06$ & 14.24 & 5269 & 262697 & 59 \\
\hline 2006-07 & 14.12 & 4721 & 255247 & 65 \\
\hline $2007-08$ & 14.06 & 5171 & 311345 & 70 \\
\hline 2008-09 & 13.86 & 5582 & 319910 & 75 \\
\hline $2009-10$ & 13.62 & 6543 & 304352 & 76 \\
\hline $2010-11$ & 13.28 & 7547 & 298421 & 78 \\
\hline Mean & 14.49 & 5562.82 & 251592.09 & 63.91 \\
\hline$C V$ & 6.36 & 15.61 & 23.05 & 15.42 \\
\hline$L G R$ & -1.81 & -2.23 & -6.23 & -4.44 \\
\hline t-value & $-14.981 * *$ & $1.103^{@}$ & $10.027 * *$ & $8.151 *$ \\
\hline
\end{tabular}

Note : **significant at 1 per cent level @ -Not significant

Source: Indian Railways Year Books 1950-51 To 2010-11

The Market share of the Indian Railways is at 30 percent to the total market share during the year 201011 in contrast to 89 percent during the year 1950-51. The market share of Indian Railways has declined drastically during the above study period. The Railway Board should tap the small consignment along with the bulk consignments. However, the Indian Railways should focus on the core activities and the non core activities should be given to the BPO.

The white paper on Indian railways states that the USA railroad length network is the largest in the entire globe while the Indian Railway stands fourth largest in the Network through the route kilometers in the entire globe.

The Chinese Railways has the largest number of Human Resource with 20.67 Lakhs while Indian Railways stands second in the deployment of Human Resource with 13 Lakhs during the year 2010-11.

Chinese Railways top's as far as the freight tones is concerned while Indian railways stand fourth largest in the entire globe. However, Indian Railways has the highest PKMS with 694764 millions followed by Chinese with 689618 PKMS in the entire globe.

\section{Conclusions}

The Indian Railways has emerged today as the main vehical for the socio- economic development of the country. Railway is a sunrise industry, not only in India but in many parts of the world. The vision for information technology in the Indian Railways for the next 25 years is to reach a stage where all the information needs of the organization can be met by a comprehensive information highway, available to all internal and external stakeholders.

The vision is to improve personal productivity at all levels by the effective use of this technology. An attempt has been made to develop a road-map for the future growth of IT in Indian Railways. Conditions today are ripe for them to obtain the benefits of IT, since general awareness of the technology is high, and its benefits have been proven. A commitment to utilize the Human Resource and IT appropriately in the organization already exists.

The Human Resource per kilometer during the year 2008-09 is about 22 is an indicator of human resource density in Indian Railways. The number of Railway stations in Indian Railways has increased significantly by 17.63 percent during the above study period depicting the network increased.

The socio-economic development in India is through the development of the railway stations. The Electrification network to the total route kilometers in Indian Railways should be enhanced substantially by 50 percent in the future years to come in order to render the best services. 
The fleet in the Indian Railways has increased substantially pertaining to the Diesel Engines, Electrical Engines, Wagons and Passenger Vehicles. The Productivity is highly significant on one hand and the contribution of Indian Railways to Indian exchequer is substantial through Net revenue of Rs 9174.45 crore on the other. The Railway Board deserves high degree of credit for the spectacular achievement.

The total cost in Indian Railways is Rs 72848.53 crore in 2008-09. The Human Resource cost to the total cost in Indian Railways is at 55 percent depicting a lion's share to the total cost in Indian Railways. The operating cost is at 90 percent during the year 2008-09.

The market share of the Indian Railways is at 30 percent to the total market share during the year 200809. Hence, the Railway Board should tap the small consignment along with the bulk consignments. However, the Indian Railways should focus on the core activities and the non core activities should be given to the BPO.

The total costs of Human Resource reduce is substantial at Rs 3, 273.46 crore during the above study period. In forthcoming 5 years the Human Resource strength may further decline in Indian Railways and in turn the Human Resource strength might be as low as 12 Lakhs by 2014-15.

However, the number of Railway Recruitment Boards should be reduced drastically to five in number and recruitment and selection ought to be on the lines of the UPSC.

About 5171 Gazetted Officers are trained and developed every year by Railway Staff College at Vadodara and by the six centralized institutions. They render yeomen's service in Indian Railways. While the number of staff trained by the zonal railway institutes have increased substantially by 164 percent during the above study period.

The implementation of the 6th pay commission resulted in decline of the net revenue during the year 2008-09. However the productivity linked bonus benefit should be extended to the group A and B officers in Indian Railways.

The cordial relations are linked with the productivity. The AIRF (All India Railwaymens Federation) and NFIR (National Federation Of Indian Railways). The recognized unions are playing a pivotal role in maintaining the cordial relations in Indian railways and also redressing the grievances of the employees in an amicable manner. The USA railroad length network is the largest in the entire globe while the Indian Railway stands fourth largest in the Network through the route kilometers. Indian Railways stands second in the deployment of Human Resource with 13 Lakh during the year 2010-11. Indian Railways stand fourth largest as far as the freight tones are concerned. However Indian Railways has the highest PKMS with 694764 millions in the entire globe. The value added reflects the contribution of the Indian Railways to the Indian exchequer. The value added by the Human Resource has increased substantially by 184 fold during the above study period. Thus, the Human Resource Management is effective in Indian Railways during the above study period.

\section{References}

[1]. Human Resource Management, Raymond A Noe and Patrick McGraw hill, COMPANIES, INC, 1997.

[2]. Personnel Management by C.B. Mamoria. Himalaya publications, New Delhi.

[3]. Statistical Techniques of Manpower Planning and Forecasting Suddhendu Biswas, 1996, New Age International Polishers. New Delhi.

[4]. TRIPATHI P.C.,"Human Resource Development": Sultan Chand and Sons, 2010, Pg. no. 44

[5]. OVASDI J. M., "Railway Administration and Management": Deep and Deep, 1990, Pg. no. 215

\section{Reports}

[6]. Indian Railways--Annual Report and Accounts, Ministry of Railways, Government of India.

[7]. Indian Railways Year Books, Ministry of Railways, Government of India.

[8]. Report by V.K.Agarwal, Chairman Railway Board

[9]. Report of Indian Defence Analysis

[10]. Report of Indian Railways

[11]. Websites

[12]. Www.preservearticles.com

[13]. www.essaydepot.com

ABOUT THE AUTHORS

V. Rajeswari is currently working as a Research Scholar, Department of Economics, S. V.University College, Tirupati. Prior to academics, she worked as Lecturer in Economics, SATAVAHANA DEGREE COLLEGE, VIJAYAWADA. For Nine years(1994-2003)

Prof. K. Santha Kumari is currently working as Professor, Dept. of Economics, S. V. University, Tirupati. Research Areas : Public Finance and Banking. Memberships in professional bodies Life MemberIndian Economic Association, A.P.Economic Association, Indian Institute of Public Administration 